\title{
Kirk St. Amant* \\ Globalizing Rhetoric: Using Rhetorical Concepts to Identify and Analyze Cultural Expectations (Specialized Knowledge) Related to Genres
}

\begin{abstract}
The growing connections among international economies means that professionals will increasingly find themselves interacting with persons from other cultures. Cultures, however, can have different expectations of what constitutes an effective professional communiqué. This article examines how the rhetorical factors of the forum, ethos, and the special topics provide a mechanism for identifying and analyzing such differences.
\end{abstract}

\section{Introduction}

As international economies become more intertwined, individuals everywhere will increasingly find themselves designing professional materials for a larger global audience. This new audience, however, brings with it different expectations of what constitutes an effective presentation of information. That is, each cultural group tends to have its own specialized knowledge related to what constitutes an acceptable and a credible presentation of information. Effective interactions within a global community - particularly a global business community or a global marketplace - thus require an understanding of such specialized knowledge. For this reason, employees and businesspersons everywhere need to be aware of how different cultural audiences might respond to their communiqués or materials. This essay addresses this need by presenting a mechanism for examining cultural communication patterns in order to identify such specialized knowledge expectations.

This essay examines how individuals can use ideas from the field of rhetoric to analyze intercultural communication situations and their re-

\footnotetext{
* Kirk St. Amant

Texas Tech University

USA

kirk.st-amant@ttu.edu

Hermes - Journal of Language and Communication Studies no 37-2006
} 
lated (and implicit) expectations. Specifically, this essay examines how the rhetorical notions of ethos (credibility/authority to present) as defined by special topics in a forum (setting/genre) can serve as an effective mechanism for both

- Analyzing cultural communication expectations in order to identify expectations related to acceptable or credible presentations of information (accessing specialized knowledge)

- Using the results of such analyses as a foundation for creating materials for different cultural audiences (applying specialized knowledge)

To address these factors, the essay is organized in the following way: It begins with an overview of how rhetorical factors related to forum and special topics' expectations establish initial credibility with a particular audience. The essay next examines how varying expectations related to these rhetorical factors can affect the perceptions cultural audiences have of the same communiqué. The essay then concludes with an examination of how these rhetorical concepts can provide a research framework for examining cultural communication expectations in order to identify specialized knowledge expectations related to credible discourse behavior.

\section{Rhetoric: an overview}

Roughly two millennia ago, the Greek philosopher and teacher Aristotle presented a system for effective communication in his treatise On Rhetoric. In this text, Aristotle defines rhetoric as, "an ability in each [particular] case to see the available means of persuasion in a given case" (1991, p. 36). Rhetoric, thus, focuses on understanding and applying a particular type of knowledge - that which is known to persuade an audience.

Classics scholars such as Forbes I. Hill (1995) have claimed that by presenting rhetoric as a method for "seeing the available means of persuasion," Aristotle intended rhetoric to have a critical/analytical function as well as a performative/creative one. As Hill explains, "Aristotle's rhetorician is a person who examines the subject before him and makes an inventory of the possibilities, especially those appropriate to this kind of auditor in situations such as this” (p. 58-59). In essence, a re- 
view of the "available means of persuasion" allows the rhetor (writer or speaker) to analyze the successful presentations of others to determine what topics to address in order to be seen as credible by that same audience (Covino \& Jolliffe, 1995; Johnson, 1984). In short, rhetoric can be used to identify the kinds of and the nature of the specialized knowledge one needs to use to persuade audiences.

From a professional communication perspective, persuasion is often related to document credibility. That is, one key job of the technical communicator is to persuade his or her audience that a document is "credible," or worth reading/using (to consider the document as having "ethos"). In essence, a credible document gets used; a non-credible document gets overlooked. Thus, the professional communicator must always take steps to persuade audiences that documents are credible, or worth using. The focus then becomes identifying the specialized knowledge one must have and use to establish such credibility.

\subsection{Ethos: the foundation of persuasive presentation}

Within this theory of persuasion exist three key pisteis, or proofs/appeals related to effective persuasion. They are logos (traditionally translated as "logic"), pathos (traditionally equated with "an appeal to emotion"), and ethos (traditionally viewed as the "credibility" or the "authority" of the presenter to speak on a given topic) (Covino \& Jolliffe, 1995). Of these three pisteis, ethos-which is characterized by displays of practical wisdom, virtue, and good will - appears to play the greatest role in persuasion. As Aristotle (1991) explains,

There are three reasons why speakers themselves are persuasive ... These are practical wisdom [phronesis] and virtue [arete] and good will [eunoia] ... Therefore, a speaker seeming to have all of these qualities is necessarily persuasive to the hearers (p. 121).

Moreover, ethos is not a fixed concept; rather, it is a creation of the presenter based on his or her audience. As an artistic proof, or pisteis, ethos is something the speaker creates through the act of presenting to an audience (McBurney, 1994; Johnson, 1984). That is, if a presenter knows the purpose for which an audience is assembled (specialized knowledge), and the presenter mentions topics related to achieving that purpose (applies that knowledge), he or she has a better chance of gai- 
ning that audience's attention. And gaining audience attention is an essential first step to then persuading that audience to do or to believe something. In achieving such ethos, the presenter needs to use his or her specialized knowledge of the purpose of a discourse situation (forum) to "become" a credible presenter in the eyes of the audience:

[I]t is necessary not only to look to the argument, that it may be demonstrative and persuasive but also [for the speaker] to construct a view of himself as a certain kind of person that hearers suppose him to be disposed toward them in a certain way and in addition if they, too, happen to be disposed in a certain way [favorably or unfavorably to him] (Aristotle, 1991, p. 120).

As different forums (purpose-based contexts) for assembling can be composed of different audiences, what a presenter needs to do to establish his or her ethos will depend on the expectations of the audience to which that person is presenting (Johnson, 1984; Hill, 1995).

The question then becomes, how does one go about establishing his or her ethos in a given discourse situation? Certain passages within On Rhetoric indicate that an effective way of creating ethos would be through appeals to a category of subjects, or "special topics," as defined by the "forum" in which the individual presents.

\section{Forums: providing the purpose for presenting}

The forum is essentially the context in which information is presented. Each forum, in turn, has its own purpose. That is, individuals come together in a particular forum in order to perform a specific task or to achieve a particular end (Walzer, 2000; Huseman, 1994).

From a professional communication perspective, the forum is essentially the genre of communication one uses to convey written or spoken information within a particular discipline or field (Berkenkotter \& Huckin, 1995). In the case of business communication, such forums/ genres might include business letters, user manuals, and online help systems. As with the physical forums (or meeting locations) of ancient Greece, readers come to the modern forums - or genres - to perform a particular kind of task (e.g., locate information, gain instruction, etc.). Or, as Carol Berkenkotter and Thomas N. Huckin (1995) explain, "Genres are dynamic rhetorical forms that are developed from actors' 
responses to recurrent situations and that serve to stabilize experience and give it coherence and meaning” (p. 4). In both cases, participants/ readers expect certain kinds of cues to be presented within that forum. Such cues, in turn, can help these participants/readers achieve the purpose for which they are assembled (Berkenkotter \& Huckin, 1995). These forum-based cues are often referred to as eide, or the special topics (Walzer, 2000; Huseman, 1994).

\subsection{The special topics: the foundation for credible presentations}

A forum is not neutral. Rather, it has a particular set of subjects or special topics that audience members (readers or listeners) expect to be addressed within the context of that forum. These special topics serve as cues the audience will look for and will use to evaluate the presenter's credibility in relation to that topic (Miller \& Selzer, 1985; Berkenkotter \& Huckin, 1995). For example, should a presenter wish to discuss online privacy, the audience will expect that presenter to address the topics of "privacy" and of "online communication" in the course of the overall presentation.

Conversely, failure to raise these topics in the context of such a forum could affect presenter credibility. That is, without mention of such topics, the audience might consider the presenter as non-credible and consider his or her presentation as not worth listening to/reading (Miller \& Selzer, 1985; Berkenkotter \& Huckin, 1995). (How, for example, do you credibly talk about online privacy without mentioning the very topics on which you are supposed to be speaking?) As a result, these special topics are essential to establishing one's ethos or authority, which is essential to gaining and keeping audience attention and interest within the context of a forum/setting (Skinner, 1996; Walzer, 2000).

In this way, the special topics become what Carolyn R. Miller and Jack Selzer (1985) might consider "origin points," for they act as a kind of marker or sign that audience members will look for to tell them "ah, this is a topic that can help me perform my given task in this forum." As Miller and Selzer explain, the more individuals are exposed to a given kind of writing (e.g., a report) - which acts as a particular kind of forum for conveying specific information - the more accustomed they become to seeing certain headings as indicating the importance of spe- 
cial information in relation to this forum (p. 311). Dorothy A. Winsor (1996) would perhaps say that these individuals are "acculturated" into the given discourse expectations of their professions. These sentiments are echoed by Berkenkotter and Huckin who note, "This [knowledge of genre expectations], rather than being specifically taught, is transmitted through enculturation as apprentices become socialized to the ways of speaking in particular disciplinary communities” (p. 7). In this way, the special topic, or heading, draws the reader's attention and ensures that the reader will pay attention to the argument that follows the mention of that special topic. As Arthur E. Walzer (2000) puts it, "The special topics are the lens through which the subject at hand (pragmata) becomes rhetorically effective" (p. 44).

Should an unexpected or non-traditional sort of heading/special topic be used, chances are that the reader will not recognize and will perhaps skip over that information or consider it less credible/less important. As Walzer (2000) explains, "subject matter relevance is more predictive of success than any other criterion” (p. 44). Moreover, this link between acculturation, credibility, and the special topics would help explain how different cultures might perceive an argument as being less credible. In such cases, a presenter from one culture has failed to touch upon the special topics members of another culture deem important to the forum (Hall, 1981; Hofstede, 1997 \& 2003). These rhetorical expectations are, in essence, a kind of specialized cultural knowledge one must therefore have in order to share information effectively and credibly with individuals from a particular culture.

\section{Using the special topics to examine specialized knowledge related to cultural presentation expectations}

A growing body of intercultural communication literature has begun to examine how cultural rhetorical expectations affect patterns of discourse within specific genres used in a culture. (See Grundy (1998), Campbell (1998), Tebeaux, (1999), and Nickerson (2000) to name but a few.) These genres, in turn, serve as forums in which certain groups of individuals meet to engage in a particular task (e.g., presenting facts, arguing for a position, conveying an opinion, etc.) (Campbell, 1998; Tebeaux, 1999; Nickerson, 2000). This focus on genre-based forums seems to be particularly apt, for while many cultures often have the same gen- 
res through which information is expressed, underlying cultural values can greatly affect what constitutes a special topic within these forums (Brisk, 1998; Campbell, 1998; Tebeaux, 1999; Bliss, 2001). Thus, genres-based specialized knowledge can vary from culture to culture, and such variations can cause miscommunication and confusion.

A good deal of indirect evidence indicates that several aspects of effective intercultural communication involve appeals to special topics in order to create one's sense of ethos in a particular genre-based forum. Elizabeth Tebeaux (1999), Charles P. Campbell (1998), and Peter Grundy (1998) all examine how different cultural expectations of business letters (the forum/genre) affect the topics audiences expect to be mentioned-or not mentioned-in those letters. Moreover, these researchers note how cultural differences related to the special topics can jeopardize the writer's credibility (ethos). Campbell, for example, points out that, within the forum of a business letter, most American readers expect direct and explicit mention of the details related to the subject of the letter. Such details become special topics for Americans, for the mention of them is essential to the writer being considered credible within the context of that forum. Failure to appeal to these topics, thus, could make the presenter appear "suspicious" and less credible in the eyes of this particular cultural audience (Ferris \& Hedgcock, 1998; Ulijn \& St.Amant, 2000).

Conversely, many Japanese readers seem to consider such topics unnecessary, for such subject matter would be considered an inherent part of the context of the genre (the letter) itself. As a result, Japanese readers might consider the appeal to American special topic of directly stating the purpose of such a memo as strange or even rude. That is, in much of Japanese culture, stating the obvious-such as the reason for which one is sending a business memo-is often seen as creating a patronizing tone (Ferris \& Hedgcock, 1998; Murdick, 1999). Thus, different cultural expectations of the special topics related to the same genre/forum can result in miscommunication and a loss of ethos.

Elizabeth Tebeaux (1999) reports similar kinds of cultural special topics distinctions in Mexican-American business letters. As Tebeaux explains, many Mexican business memos contain appeals to identity (identifying ones' self as being an acquaintance of someone who is close to the reader) and to family. In this genre, writers are expected to 
address these topics if they wish to be considered worthy of the readers' attention (seen as having ethos). Tebeaux notes that

\begin{abstract}
Mexico's historic emphasis on the family, a value prevalent even in contemporary Mexican society, finds its way into recommended methods of conducting business and into written business communication ... the traditional Mexican business letter establishes rapport by commenting, in the introduction, about family and/or mutual friends (p. 51 \& 54).
\end{abstract}

Should a writer fail to address the special topic of family relations particularly how the writer is connected to the reader by mutual family members - he or she will often be dismissed as not credible enough by many Mexican readers, "who want to know with whom they are dealing” (Tebeaux, 1999, p. 51). Thus, failure to address the special topics expected by a culture in a particular forum/genre can cost one credibility/ethos with readers from that culture.

Other researchers, such as Steven E. Weiss (1998), note additional differences in culture-based special topics related to the forum of negotiations. Weiss' work reveals how six different cultures (Mainland Chinese, French, Japanese, Mexicans, Nigerians, and Saudis) use six rather different persuasive methods/strategies, each linked to raising a different kind of topic within the same forum. For example, the Chinese tend to create presenter credibility by addressing the topics of, "mutual interest and friendship" vs. French presenters who create initial credibility by appealing, “. . . to universal truths (experiences) and feelings and preferences (intuition), and carries emotional intensity (elan)” (Weiss, 1998, p. 66 \& 79).

Other kinds of culture-based special topics problems have been noted by Victoria M. Mikelonis (2000) in her experiences teaching the genre/forum of grant and proposal writing in Eastern Europe. As she explains, certain special topics that many Americans consider essential to creating initial credibility when writing an effective grant proposal often don't exist in many Eastern European cultures. For example, to many Poles, the concept of "market" is completely different from what many American or Western European investors might think of when they hear the word. As Mikelonis notes, "The only word the Poles had for 'market' was 'targ' which referred to the local farmer's market in the town square" (p. 216). Thus, in relation to an international business 
transaction, it is perhaps safe to assume that many Poles would probably not consider it necessary to raise the notion of markets in the forum/genre of a grant proposal.

However, to apply for the American and Western European grants essential to revitalizing their economy, the Poles needed to make direct mention of markets. Thus, for Mikelonis, the task became teaching her Polish students the special topics expected in the American or the Western European grant writing forum so that Polish-authored grants would be viewed as credible by American funding agencies. As Mikelonis explains, "Since they [the Poles] would look to the United States for joint venture partners and strategic alliances, we would teach them how to communicate effectively with American financiers and, in the process, describe how the market economy operates in the United States” (p. 216).

\section{Applying rhetorical ideas to analyse cultural communicaton practices}

By following a few, key steps based on rhetorical ideas of the forum, ethos, and the special topics, today's professionals can effectively analyze materials produced by individuals from other cultures. This analysis can, in turn, provide a guide for designing materials for individuals from these cultures. The same devices can also function as a guide researchers can use to explore the nuances of culture and communication in more detail.

To implement these rhetorical factors for such analyses, individuals should first review documents produced by natives of the desired target culture (cultural audience for which they are designing materials). Such an analysis would allow interested parties to develop an effective strategy for designing materials that individuals from a specific culture would consider "credible" or "worth using." These ideas should then be used to perform for the following four rhetorical analytical tasks:

\section{Identify the forum (genre) of writing}

While this step might seem self-obvious, it could be one of the more overlooked and problematic aspects of cross-cultural communication. The problem is the assumption that all cultures have or use the same kinds of genre-based forums for presenting information. (In fact, the 
apparent self-obviousness of this step has, perhaps, caused many individuals to overlook the importance of this initial step.) In truth, what might be considered "relatively common" forums/genres in one culture might not exist in another. Kristin R. Woolever (2001), for example, notes that, "in many high-context cultures [e.g., Japan, China, Saudi Arabia] people rely on more informal relationships [i.e., personal conversations] and discussions to establish the foundations and standards for proposals" (p. 56). As a result, "they may thus view as unnecessary and perhaps as offensive the use of written Requests For Proposals (RFPs)" (Woolever, 2001, p. 56).

Thus, it appears that different cultures could have different kinds of forums/genres they use to convey information. In the case mentioned by Woolever (2001), the American expectation that the forum/genre of RFPs exists in other cultures could result in miscommunication or offense when presented to individuals from cultures that might not have such a forum. From a rhetorical perspective, it is a case of ethos/credibility being lost through failure to understand (lack of specialized knowledge of) the forum in which information is expected to be presented. Thus, individuals should always begin their research, analysis of materials, and design process by asking,

Does the genre I want to use to convey information exist in the culture with which I will be sharing that information?

\section{Identify the purpose of the forum (genre)}

As mentioned earlier, forums are generally organized around a particular purpose. This purpose is, in turn, often linked to a particular context in or through which information is presented. The context of a courtroom, for example, implies the purpose of finding an accused individual to be guilty or innocent. Similarly, the context of a progress report assumes the purpose of providing someone with an update on a particular project. Thus, forums/genres are often associated with or identified by a particular context (Berkenkotter \& Huckin, 1995). However, just because two cultures appear to have the same forums/genres for conveying information does not mean that both cultures see that forum as related to a similar purpose. 
Many Americans, for example, view the forum/context of the business letter as related to serving the purpose of sharing information and specific details related to performing a particular business-related task (Ober, 1998; Perelman, Paradis, \& Barrett, 1998). Individuals from certain Asian cultures, however, often view the forum of a business letter as associated with the purpose of establishing or re-enforcing long-term relationships with the letter's recipients (Campbell, 1998; Hofstede, 1997 \& 2003). As a result of these differences, confusion could result for one side (the recipient) wonders why the other is addressing unnecessary or inappropriate subjects (subjects that are directly related to the sender's perception of the purpose of the forum) in that forum. Presentations that appear unrelated to the purpose of the forum, therefore, could make the sender appear "unprofessional" - or cost that person ethos (credibility) - because that person raised "non-relevant" topics in that particular forum/genre. Again, a lack of specialized knowledge related to genre expectations results in cross-cultural communication problems.

For example, a Japanese business letter that attempts to establish long-term relationships could be dismissed by American readers who might consider these attempts non-germane or as "beating around the bush” (Ulijn \& St.Amant, 2000). Similarly, many Japanese readers might consider an American business memo, which is often used for the purpose of conveying specific information related to business processes, as rude due to the fact it is "too direct," which might be taken to imply that the sender does not wish to establish long-term relations with the recipient (Campbell, 1998). In short, just because a culture has a particular forum/genre does not mean that forum serves a similar function in that culture. Rather, once individuals have determined a culture has a particular forum, those persons should next ask,

What purpose does this forum serve in this culture?

\section{Identify the special topics related to achieving the purpose of the forum}

As noted, the special topics are generally those items one needs to address to fulfill the purpose of a forum. Because cultures might have different purposes related to a forum, different cultures might also expect different kinds of special topics to be addressed in that forum. Thus, 
the next step individuals must take is to review documents produced by a target audience to determine what special topics are being raised in order to achieve the purpose of the forum. In this case, if one knows the purpose a forum serves in a given culture, one can better identify the special topics used to achieve that purpose.

In the cases of Japanese business letters, for example, the purpose of that forum is to establish long-term relations with the reader. One way to achieve this end is for the writer to present his or her knowledge of the reader/recipient (Campbell, 1998). The idea is that by revealing one's knowledge about the letter's recipient, the sender is displaying his or her interest to form a long-term relationship with that recipient - otherwise, why would the sender have taken the time to learn those facts (Campbell, 1998)? In this way, displaying knowledge about the reader's background becomes a special topic many Japanese readers will look for in the genre of a business letter.

Charles P. Campbell (1998), for example, has noted a case in which a Chinese writer includes a mention of the names of the four main islands of Japan in a memo to a Japanese reader. Yet the inclusion of such a statement - which is probably common knowledge to many Japanese readers - appears odd to American cultural sensibilities: "[W]hy do Japanese readers need to be told the names of their four main islands?" (Campbell, 1998, p. 39). Such a mention might be seen as comparable to making American readers aware of the fact that the United States contains the states of New York, California, and Texas. The mention of such "self-obvious" information, however, is an important special topic related to creating credibility with many members of a Japanese or a Chinese audiences.

Campbell explains that in much of Chinese and Japanese culture, credibility often results from demonstrating a knowledge of the reader. Demonstrating such knowledge is essential to establishing long-term relations in these cultures (Hofstede, 1997 \& 2003). Moreover, in both cultures, such long-term relationships tend to be valued above others (Hofstede, 1997 \& 2003). Thus, to many Japanese and Chinese readers, a display of knowledge of the other party becomes a special topic the presenter notes in order to address the forum's purpose-creating a long-term relationship. Mention of an expected special topic related to 
the purpose of a forum is therefore essential to establishing credibility in the eyes of that audience.

In the case of Campbell's (1998) example, the Chinese individual is trying to display his knowledge of the reader's country to indicate an interest in establishing a long-term relationship with the reader. As Campbell explains, "So when in the last paragraph [of the memo] the writer finally delivers the message of congratulations, he has already built a relationship with his reader and the message carries some weight [i.e., ethos]" (p. 39).

While these "relationship-related" special topics are important to achieving the purpose of a business letter in much of Japanese and Chinese culture, addressing these same topics in the same forum with American readers could result in confusion and a loss of credibility. This confusion results from the fact that most American readers see the forum of the business letter as serving another kind of purpose: presenting information related to business practices or business decision making (Ober, 1998; Perelman, Paradis, \& Barrett, 1998). For this reason, most American readers come to the forum of the business letter looking for a different kind of special topics needed to accomplish a different purpose. Thus, the special topics most American readers look for in a business letter are explicit mentions of information (usually specific information) related to the business process/activity in which the letter's sender and recipient are engaged at that time (Ober, 1998; Perelman, Paradis, \& Barrett, 1998). This cultural difference in purpose could, therefore, result in miscommunication and a loss of credibility as readers from one culture do not find the special topics they need to accomplish the purpose they associate with a particular forum. Thus, once individuals have identified the purpose for which a cultural audience uses a particular forum, those individuals should then ask two key questions:

What (special) topics do I need to address in order to achieve the purpose of this forum (and present my document as credible)?

And

What (special) topics do readers from my culture expect to be addressed in this forum, for if they are different from what my target cultural audience expects, addres- 
sing them could confuse the target audience and cost me credibility?

\section{Understand the proper presentation format of the special topics}

While identifying culture specific special topics might seem relatively easy, using them effectively is another matter. This problem is related to the fact that the point at which one is expected to address a particular special topic can be as crucial to establishing credibility within a forum as addressing the topic itself. Additionally, the factor of timing can vary from culture to culture. In the cases of Japanese or Mexican business letters, for example, the purpose of that forum is to try to establish long-term relations with the reader (Campbell, 1998; Tebeaux, 1999). As mentioned, in many Japanese business letters, one way to address this end is to raise the special topic of knowledge of the reader/recipient (or his or her culture) (Campbell, 1998). In most Mexican business letters, the idea is to reveal that the writer and the recipient are related via some distant family tie or mutual acquaintance (Tebeaux, 1999). Thus, both sets of cultural expectations bring with them the use of different kinds of special topics to accomplish the forum's overall goal.

But these topics cannot be randomly addressed or haphazardly within the course of the forum. Rather, cultural audiences seem to expect that these special topics will be raised in a certain order or at a certain point within the forum. As certain individuals have noted, business letters to Japanese audiences should begin with a "formal courtesy" and some sentiment that indicates the writer has some knowledge of the reader's company or culture (Murdick, 1999; Driskill, 1996). Next, the writer might wish to raise the mutual goal that both parties (sender and recipient) can work toward. Finally, toward the conclusion, one can subtly raise the "business" function the letter is designed to serve (e.g., an update or an evaluation or a formal record) (Campbell, 1998). Failure to follow this sequence for raising these culture-specific special topics could result in problems. Instead, it appears that one must first attempt to display the desire to form a long-term relationship with the letter's recipient before discussing the more "nuts-and-bolts" purposes for sending the letter. To do otherwise might be seen as too brazen of a move.

A related pattern can be seen in many Mexican business letters. In this case, the writer needs to establish his or her credibility by showing 
some sort of family relation with the letter's recipient or show that the two parties share a mutual acquaintance. This "appeal to mutual relations/acquaintances" tends to come early in the letter as the purpose of that forum is to establish one's long-term ties to the reader early on. In this case, however, the actual "business" purpose of the letter might never be raised directly (Tebeaux, 1999). Rather, it is often left up to the reader to "fill in the blanks" when determining the business function of the letter. Again, attempts to get to that business function (or even directly raising it) of a letter without first attempting to establish family or acquaintance based relations could lead to insult (e.g., "Who is this person to be addressing me this way/contacting me like this?”). Such insult could, in turn, result in the message being seen as non-credible and not worthy of reading. For this reason, individuals need to review documents written by natives of a target cultural audience and ask not only,

What are the special topics that I need to address in this forum?

but also

In what order or sequence do I need to present/raise these special topics in order to appear credible in the eyes of the reader?

This order can then be followed when presenting special topics in materials designed for members of the particular target culture.

\section{Culture and communication expectations}

By reviewing documents designed by individuals from particular target cultures, individuals can begin to understand the patterns and strategies (specialized knowledge) these individuals use to create effective documents. Through an analysis based on the four categories mentioned in the previous section, persons can develop a better understanding of cultural communication preferences and can create more credible documents for different cultural audiences.

In proposing such a special topics analysis and creation mechanism, however, certain additional factors need to be discussed. First, cultural expectations of forums, ethos, and the special topics are not innate. Rat- 
her, as Iris Varner and Linda Beamer (1995) and as Maria Estela Brisk (1998) and Bertha Perez (1998) all explain, such expectations are learned over time as individuals are "socialized" into the rhetorical preferences of their given culture. These sentiments nicely parallel those of Miller and Selzer (1985) and Berkenkotter and Huckin (1995), who all noted that genre knowledge is transmitted in this kind of acculturation process.

While these cultural expectations do shape the rhetorical process we use when communicating with individuals from other cultures, these preferences are not absolute. Rather, over time, one can learn how to communicate with members of another other culture according to the rhetorical patterns and expectations of that culture (Campbell, 1998; Panetta, 2001). However, as Jan M. Ulijn's (1996) research suggests, we use our native rhetorical expectation to judge communiqués, even when they are written in other languages or by persons from other cultures. Moreover, English as a Second Language (ESL) research notes similar trends revealing that, "we transfer our writing knowledge and skills [i.e., our rhetorical preferences] to a second language" (Perez, 1998, p. 59). Thus, no matter how deeply individuals attempt to entrench themselves in another culture or how fluent they are in another language, the cultural rhetorical expectations of a person's native culture still affect how an individual perceives and interacts with others.

Second, as Dorothy Winsor (1996) points out, individuals are also acculturated or socialized into the communication norms of their related professions. As Winsor explains, "These professional writing contexts both created the demands that their [interns'] writing had to meet and provided support that helped them to do so in the form of experienced writers and established texts" (p. 21). The question then becomes will individuals who are from different cultures but who have similar jobs within the same corporate organization have different rhetorical expectations? In short, which culture exercises a greater control over one's rhetorical expectations: is it national culture or professional culture?

To answer this question, the Dutch sociologist Geert Hofstede (1997 \& 2001) conducted a massive research project in which thousands of IBM employees in 50 different countries responded to a series of standardized questions. Hofstede's goal was to compare individuals from 
different cultures but similar professional backgrounds to determine the effects one culture might have on the other. His findings reveal that, despite professional similarities, there is a distinct national cultural character that accounts for why persons from particular cultures respond differently to similar situations (Hofstede, 1997 \& 2003). Similar kinds of findings have also been noted by Fons Trompenaars and Charles Hampden-Turner (1998). Based on these results, it seems reasonable to assume that culture-based forum and special topic differences can serve as an effective mechanism for analyzing cross-cultural discourse in professional settings.

\section{Conclusion}

As electronic communication technologies increase contact among cultural groups, professionals in a variety of fields will certainly find themselves designing materials for a growing international audience. As different cultures can have different expectations of what constitutes "good" communication, it is important that today's businesspersons and their employees understand the rhetorical concepts readers might look for when evaluating documents. This essay has overviewed how an understanding of the rhetorical concepts of the forums, ethos, and the special topics can serve as powerful analytical tools for better understanding the communication expectations of different cultural audiences. By using four rhetorical strategies/approaches to analyze materials from other cultures, individuals can gain a better understanding of what they need to do to design effective documents for members of that culture. Such an understanding, in turn, could be essential to success in this age of intertwined national economies and increased global trade.

\section{References}

Aristotle 1991: On rhetoric. Trans. George A. Kennedy. New York: Oxford University Press.

Berkenkotter, C. \& Huckin, T. H. 1995: Genre knowledge in disciplinary communication: Cognition/culture/power. Hillsdale, NJ: Lawrence Erlbaum Associates.

Bliss, A. 2001: Rhetorical structures for multilingual and multicultural students. In C. G. Panetta (Ed.), Contrastive rhetoric revisited and redefined (pp. 15-30). Mahwah, NJ: Lawrence Erlbaum Associates. 
Brisk, M. E. 1998: Bilingual education: From compensator to quality schooling. Mahwah, NJ: Lawrence Erlbaum Associates.

Campbell, C. P. 1998: Rhetorical ethos: A bridge between high-context and low-context cultures? In S.Niemeier, C. P. Campbell, and R. Dirven (Eds.), The cultural context in business communication (pp. 31-47). Philadelphia, PA: John Benjamins Publishing Company.

Covino, W. A. \& Jolliffe, D. A. 1995: What is rhetoric? In W. A. Covino and D. A. Jolliffe (Eds.), Rhetoric: Concepts, definitions, boundaries (pp. 3-8). Boston: Allyn and Bacon.

Driskill, L. 1996: Collaborating across national and cultural borders. In D. C. Andrews (Ed.), International dimensions of technical communication (pp. 23-44). Alexandria, VA: Society for Technical Communication.

Ferris, D. \& Hedgcock, J. S. 1998: Teaching ESL composition: Purpose, process, and practice. Mahwah, NJ: Lawrence Erlbaum Associates.

Grundy, P. 1998: Parallel texts and divergent cultures in Hong Kong: Implications for intercultural communication. In S. Niemeier, C. P. Campbell, and R. Dirven (Eds.), The cultural context in business communication (pp. 167-183). Philadelphia: John Benjamins Publishing Company.

Hill, F. I. 1995: Aristotle's rhetorical theory: With a synopsis of Aristotle’s rhetoric. In J. J. Murphy and R. A. Katula (Eds.), A synoptic history of classical rhetoric $2^{\text {nd }}$ ed. (pp. 51-109). Davis, CA: Hermagoras Press.

Hall, E. T. 1981: The silent language. New York: Anchor Books.

Hofstede, G. 2003: Culture's consequences $2^{\text {nd }}$ ed. Thousand Oaks, CA: Sage Publications.

Hofstede, G. (1997). Cultures and organizations software of the mind: Intercultural cooperation and its importance for survival. New York: McGraw-Hill.

Huseman, R. C. 1994: Aristotle's system of topics. In E. Schiappa (Ed.), Landmark essays on classical Greek Rhetoric. (pp. 191-199). Davis, CA: Hermagoras Press.

Johnson, N. 1984: Ethos and the aims of rhetoric. In R. J. Connors, L. S. Ede, and A. A. Lunsford (Eds.), Essays on classical rhetoric and modern discourse. (pp. 98-114). Carbondale, IL: Southern Illinois University Press.

McBurney, J. H. 1994: The place of the enthymeme in rhetorical theory. In E. Schiappa (Ed.), Landmark essays on classical Greek rhetoric. (pp. 169-190). Davis, CA: Hermagoras Press.

Mikelonis, V. M. 2000: Message sent versus message received: Implications for designing training materials for Central and Eastern Europeans. In P. J. Hager and H. J. Scheiber (Eds.), Managing global communication in science and technology. (pp. 203-231). New York: John Wiley \& Sons, Inc.

Miller, C. R. \& Selzer, J. 1985: Special topics of argument in engineering reports. In L. Odell and D. Goswami (Eds.), Writing in non-academic settings. (pp. 309-341). New York: Guilford. 
Murdick, W. 1999: The portable business writer. New York, NY: Houghton Mifflin.

Nickerson, C. 2000: Playing the corporate language game: An investigation of the genres and discourse strategies in English used by Dutch writers working in multinational corporations. Atlanta: Rodopi.

Ober, S. 1998: Contemporary business communication $3^{\text {rd }}$ edn. New York: Houghton Mifflin.

Panetta, C. G. 2001: Understanding cultural differences in the rhetoric and composition classroom: Contrastive rhetoric as answer to ESL dilemmas. In C. G. Panetta (Ed.), Contrastive rhetoric revisited and redefined. (pp. 3-13). Mahwah, NJ: Lawrence Erlbaum Associates.

Perelman, L. C., Paradis, J. \& Barrett, E. 1998: The Mayfield handbook of technical and scientific writing. Mountain View, CA: Mayfield.

Perez, B. 1998: Writing across writing systems. In B. Perez (Ed.), Sociocultural contexts of language and literacy. (pp. 49-65). Mahwah, NJ: Lawrence Erlbaum Associates.

Skinner, Q. 1996: Reason and rhetoric in the philosophy of Hobbes. New York: Cambridge University Press.

Tebeaux, E. 1999: Designing written business communication along the shifting cultural continuum: The new face of Mexico. Journal of Business and Technical Communication 13, 49-85.

Trompenaars, F. \& Hampden-Turner, C. 1998: Riding the waves of culture: Understanding diversity in global business $2^{\text {nd }}$ ed. New York: McGraw-Hill.

Ulijn, J. M. 1996: Translating the culture of technical documents: Some experimental evidence. In D. C. Andrews (Ed.), International dimensions of technical communication. (pp.69-86). Arlington, VA: Society for Technical Communication.

Ulijn, J. M. \& St.Amant. K. 2000: Mutual intercultural perceptions: How does it affect technical communication? Some data from China, the Netherlands, Germany, France, and Italy. Technical Communication 47, 220-237.

Varner, I. \& Beamer, L. 1995: Intercultural communication in the global workplace. Boston: Irwin.

Walzer, A. E. 2000: Aristotle on speaking 'outside the subject': The special topics and rhetorical forums. In A. G. Gross and A. E. Walzer (Eds.), Reading Aristotle's Rhetoric. (pp. 38-54) Carbondale, IL: Southern Illinois University Press.

Weiss, S. E. 1998: Negotiating with foreign business persons: An introduction for Americans with propositions on six cultures. In S. Neimeier, C. P. Campbell, and R. Dirven (Eds.), The Cultural Context in Business Communication. (pp.51-118). Philadelphia: John Benjamins Publishing.

Winsor, D. A. 1996: Writing like and engineer: A rhetorical education. Mahwah, NJ: Lawrence Erlbaum Associates.

Woolever, K. R. 2001: Doing global business in the information age: Rhetorical contrasts in the business and technical professions. In C. G. Panetta (Ed.), Contrastive 
rhetoric revisited and redefined. (pp. 47-64). Mahwah, NJ: Lawrence Erlbaum Associates. 